\title{
Bacterial species other than Renibacterium salmoninarum cross-react with antisera against $R$. salmoninarum but are negative for the p57 gene of $R$. salmoninarum as detected by the polymerase chain reaction (PCR)
}

\author{
L. L. Brown ${ }^{1,2, *}$, T. P. T. Evelyn ${ }^{2}$, G. K. Iwama ${ }^{1}$, W. S. Nelson ${ }^{3, * *}$, R. P. Levine ${ }^{3}$ \\ 'Department of Animal Science, Canadian Bacterial Diseases Network, University of British Columbia, No. 248 - 2357 Main Mall, Vancouver, \\ British Columbia, Canada V6T 1Z4 \\ ${ }^{2}$ Biological Sciences Branch, Department of Fisheries and Oceans, Pacific Biological Station, 3190 Hammond Bay Road, Nanaimo, \\ British Columbia, Canada V9R 5K6 \\ ${ }^{3}$ Hopkins Marine Station, Stanford University, Oceanview Blvd, Pacific Grove, California 93950-3094, USA
}

\begin{abstract}
Genomic DNA was extracted from 4 strains of Carnobacterium piscicola and 2 strains of Corynebacterium aquaticum that had previously been reported to produce a $57 \mathrm{kDa}$ protein that reacted with polyclonal antiserum against Renibacterium salmoninarum. Genomic DNA was also extracted from a Gram-negative bacterium isolated from the kidney tissue of a mature female coho salmon Oncorhynchus kisutch. The bacterium, tentatively identified as Pseudomonas maltophila, cross-reacts with 2 polyclonal antisera, one of which is used in an enzyme-linked immunosorbent assay and the other in a fluorescent antibody test to identify $R$. salmoninarum. The isolate of $P$. maltophila, and the Carnobacterium piscicola and Corynebacterium aquaticum strains, were negative by a polymerase chain reaction (PCR) that was designed to amplify a segment of the gene encoding p57, a major protein of $R$. salmoninarum. These results suggest that although antibodies directed against $R$. salmoninarum crossreact with antigens of bacterial species other than $R$. salmoninarum, the cross-reacting antigen(s) is clearly not the same protein, as the non- $R$. salmoninarum bacteria lacked the gene encoding $\mathrm{p} 57$. These findings highlight some of the shortcomings of immunodiagnostic tests for detecting $R$. salmoninarum and indicate the high degree of specificity associated with a PCR-based diagnostic technique
\end{abstract}

KEY WORDS: PCR - DNA - BKD detection - Salmon eggs · Bacterial disease Broodstock screening

The 2 immunodiagnostic techniques most commonly used to detect infections with Renibacterium salmoninarum, causative agent of bacterial kidney disease (BKD), are the fluorescent antibody test (FAT) and the

\footnotetext{
- Address correspondence to Nanaimo address

-Present address: Genetics Department, Life Sciences Building, University of Georgia, Athens, Georgia 30602, USA
}

enzyme-linked immunosorbent assay (ELISA) (Elliott et al. 1989). The antisera used in these tests are raised in mammals against whole, killed $R$. salmoninarum cells (Bullock et al. 1980, Evelyn et al. 1981, Elliott \& Barila 1987), or against one of the dominant antigens of $R$. salmoninarum: a $57 \mathrm{kDa}$ protein known as p57 (Turaga et al. 1987. Sakai et al. 1992). Fluoresceinconjugated antisera used in the FAT have been shown to react with bacterial species other than $R$. salmoninarum (Bullock et al. 1980, Austin \& Rayment 1985 , Yoshimizu et al. 1987, Barbash 1992, Foott et al. 1992, Brown et al. 1994). Similarly, false-positive $R$. salmoninarum reactions have been reported with the ELISA (Dixon 1985, Turaga et al. 1987). In attempts to avoid false-positive reactions, some workers have used monoclonal antibodies directed against selected epitopes of p57 (Wiens \& Kaattari 1989, Hsu et al. 1991, Rockey et al. 1991). Others have used Western blot analysis to make the diagnosis less equivocal (Olivier et al. 1992). That technique is based on demonstrating that the serologically reactive antigen migrates in an SDS polyacrylamide electrophoretic gel to a position identical to that of p57. The Western blot technique, however, is insufficiently sensitive to detect very small amounts of the p57. Consequently Olivier et al. (1992) concluded that it was only suitable for diagnosing relatively active $R$. salmoninarum infections.

Recently Bandin et al. (1993) and Toranzo et al. (1993) detected a $57 \mathrm{kDa}$ protein in 2 species of bacteria, Carnobacterium piscicola and Corynebacterium aquaticum, that reacted with antisera raised against Renibacterium salmoninarum. These authors did not indicate whether the presence of this protein also 
caused a cross-reaction in the FAT or ELISA, but the finding did raise the possibility that p57 might not be unique to $R$. salmoninarum. More recently, Brown et al. (1994) identified tissues from salmon that were positive for $R$. salmoninarum by the FAT but were negative for the pathogen by the more sensitive polymerase chain reaction (PCR). That discrepancy was caused by the presence of a cross-reacting bacterium, since tentatively identified as Pseudomonas maltophila.

The purposes of this study were, first, to determine whether strains of Carnobacterium piscicola and Corynebacterium aquaticum and Pseudomonas maltophila yielded false-positive reactions in both the FAT and ELISA, and second, to determine whether these organisms possess the gene encoding the p57 molecule as detected by the PCR.

Materials and methods. Salmonid tissue samples: Kidney tissues were aseptically removed from a female coho salmon from Robertson Creek Salmon Enhancement Hatchery (Port Alberni, BC, Canada), homogenized, and then assayed for the presence of Renibacterium salmoninarum by ELISA and FAT, as described previously (Brown et al. 1994).

Bacteria: A bacterium was isolated from the salmonid kidney tissue (Table 1) by streaking the tissue homogenate onto Tryptic Soy Agar (TSA; Difco, Detroit, MI, USA) and selective Kidney Disease Medium (SKDM-C) (Austin et al. 1983, Daly \& Stevenson 1985). The plates were then incubated at $15^{\circ} \mathrm{C}$ ( 24 to $48 \mathrm{~h}$ for TSA and up to 8 wk for SKDM-C). Bacterial growth from the TSA plates was subcultured at least 3 times, after which the cells were harvested from the plates, suspended in sterile saline $(0.85 \%)$, and subjected to the ELISA, FAT, and the Gram stain. Biochemical tests on the bacterium were also done using an API kit (API Analytab Products, Plainview, NY, USA) according to the manufacturer's instructions. These tests yielded a profile consistent with that of Pseudomonas maltophila: the bacterium was positive in the features $\beta$-galactosidase, lysine decarboxylase, citrate utilization, gelatin liquefaction, glucose utilization, $\mathrm{NO}_{2}$ reduction; and negative in the reactions arginine dihydrolase, ornithine decarboxylase, $\mathrm{H}_{2} \mathrm{~S}$ production, urease, tryptophane deaminase, indole, Voges-Proskauer, mannose, inositol, sorbitol, rhamnose, sucrose, melibiose, and arabinose utilization, amylase, oxidase, and $\mathrm{CO}_{2}$ production.

Carnobacterium piscicola strains ATCC 35586, PT-31, HB-245, and HB246, and Corynebacterium aquaticum strains ATCC 14665, and 968BA were kindly donated by Dr A. Toranzo (Departamento de Microbiología y Parasitología, Facultad de Biología, Universidad de Santiago de Compostela, Santiago de Compostela, Spain) (Table 1). They were grown at room temperature on brain heart infusion agar (BHIA) supplemented with $1 \%(\mathrm{v} / \mathrm{v})$ bovine serum. The bacterial growth was aseptically scraped off the plates and suspended in sterile saline. Aliquots of the suspensions were kept at $-80^{\circ} \mathrm{C}$ until required for DNA extraction. Additional aliquots of the suspensions were used in the ELISA

ELISA and FAT: An ELISA was performed on the suspensions of the Pseudomonas maltophila, Carnobacterium piscicola and Corynebacterium aquaticum strains using a commercially available antiserum raised against Renibacterium salmoninarum cells in goats (Kirkegaard \& Perry Laboratories, Gaithersburg, MD, USA), as described by Brown et al. (1994). The FAT, also as described by Brown et al. (1994), was performed on all bacterial strains. Cells of $R$. salmoninarum (strain 384) from the Pacific Biological Station in Nanaimo, BC (Table 1), were used as positive controls for these assays. In order to ensure that any differences observed in these immunoassays were qualitative and not quantitative, all cell suspensions were diluted to give an absorbance of 2.5 at $420 \mathrm{~nm}$ corresponding to ca $10^{8}$ cells $\mathrm{ml}^{-1}$.

DNA extraction: DNA for the PCR tests was extracted from the Pseudomonas maltophila isolate, Renibacterium salmoninarum (ATCC strain 33209), the 4 Carnobacterium piscicola strains, and from the 2 Corynebacterium aquaticum strains by a phenol' chloroform method (Sambrook et al. 1989).

PCR: The PCR was performed according to a previously described protocol (Brown et al. 1994) using primers designed to amplify a 501 base-pair segment

Table 1. Provenance of bacterial strains examined by PCR

\begin{tabular}{|c|c|c|}
\hline Species & Strain & Provenance \\
\hline $\begin{array}{l}\text { Renibacterium } \\
\text { salmoninarum }\end{array}$ & $\begin{array}{l}\text { ATCC } 33209 \\
\text { Rs } 384\end{array}$ & $\begin{array}{l}\text { Oncorhynchus tshawytscha, USA } \\
\text { O. tshawytscha, Canada }\end{array}$ \\
\hline $\begin{array}{l}\text { Unknown Gram- } \\
\text { negative, tentatively } \\
\text { identified as Pseudo- } \\
\text { monas maltophila }\end{array}$ & & $\begin{array}{l}\text { O. kisutch, Robertson Creek, } \\
\text { British Columbia, Canada }\end{array}$ \\
\hline $\begin{array}{l}\text { Carnobacterium } \\
\text { piscicola }\end{array}$ & $\begin{array}{l}\text { ATCC } 35586 \\
\text { PT-31 } \\
\text { HB-245 } \\
\text { HB-246 }\end{array}$ & $\begin{array}{l}\text { O. clarki, USA } \\
\text { Morone saxatilis, USA } \\
\text { M. saxatilis, USA } \\
\text { O. mykiss, Spain }\end{array}$ \\
\hline $\begin{array}{l}\text { Corynebacterium } \\
\text { aquaticum }\end{array}$ & $\begin{array}{l}\text { ATCC } 14665 \\
968 \mathrm{BA}\end{array}$ & $\begin{array}{l}\text { Distilled water, USA } \\
M \text {. saxatilis, USA }\end{array}$ \\
\hline
\end{tabular}


of the Renibacterium salmoninarum gene encoding p57.

Results. In the FAT, fluorescing bacterial cells were observed in the kidney homogenates obtained from. the Robertson Creek female coho salmon. These cells were too long (5 to $10 \mu \mathrm{m}$ long) to be Renibacterium salmoninarum, as reported previously (Brown et al. 1994). The Gram-negative Pseudomonas maltophila, harvested from the TSA plates after subculturing, were also positive by the FAT, and were the same large size as the cells seen in the kidney homogenates. In contrast, no fluorescence was observed in the Corynebacterium aquaticum and Carnobacterium piscicola strains in the FAT. The kidney homogenates from the Robertson Creek female coho salmon also yielded a positive result in the ELISA: the optical density (OD) values observed were higher than the positive threshold established by Meyers et al. (1993) for salmonid kidney tissues (Brown et al. 1994). Similarly, the ELISA performed on the $P$. maltophila cells subcultured on TSA and suspended in saline also yielded positive OD values (Table 2). The ELISA performed on the Carnobacterium piscicola and Corynebacterium aquaticum isolates yielded negative results in 5 strains. One strain of Carnobacterium piscicola (strain PT-31) yielded moderately positive results (Table 2 ). When

Table 2. Results of enzyme-linked immunosorbent assay (ELISA) performed on isolates of Renibacterium salmoninarum, Pseudomonas maltophila, Carnobacterium piscicola and Corynebacterium aquaticum, using a commercially available antiserum raised against $R$. salmoninarum in goats. Suspensions of bacteria used in the tests were standardized [ 2.5 optical density (OD) at $420 \mathrm{~nm}$ ]. OD values at $410 \mathrm{~nm}$ are given as the means ( \pm SD) of triplicates. Negative control was a homogenate of kidney tissue from a coho salmon Oncorhynchus kisutch that gave OD values in the ELISA below the threshold value $(0.095)$ established for $R$. salmoninarum-positive salmon (Meyers et al. 1993)

\begin{tabular}{|lll|}
\hline Species & \multicolumn{1}{c}{ Strain } & OD at $410 \mathrm{~nm}$ \\
\hline Negative control & & $0.083 \pm 0.004$ \\
$\begin{array}{l}\text { Renibacterium } \\
\text { salmoninarum } \\
\text { (positive control) }\end{array}$ & 384 & $0.304 \pm 0.015$ \\
& & \\
$\begin{array}{l}\text { Pseudomonas } \\
\text { maltophila }\end{array}$ & & $0.171 \pm 0.004$ \\
$\begin{array}{l}\text { Carnobacterium } \\
\text { piscicola }\end{array}$ & ATCC 35586 & $0.096 \pm 0.001$ \\
& PT-31 & $0.106 \pm 0.004$ \\
& HB-425 & $0.087 \pm 0.004$ \\
Corynebacterium & ATC-426 14665 & $0.095 \pm 0.003$ \\
aquaticum & 968BA & $0.092 \pm 0.003$ \\
& & $0.084 \pm 0.002$ \\
\hline
\end{tabular}

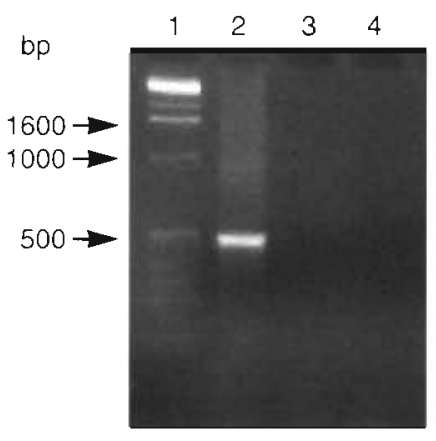

Fig. 1 Agarose gel electrophoresis of amplification products from DNA extracted from Renibacterium salmoninarum and the bacterial isolate tentatively identified as Pseudomonas maltophila. Lane 1: molecular weight markers (base pairs, $\mathrm{bp)}$; Lane 2: $3.72 \mu \mathrm{g} \mathrm{m}^{-1} R$. salmoninarum template DNA; Lane 3: $6.15 \mathrm{\mu g} \mathrm{ml} \mathrm{g}^{-1}$ bacterial isolate $P$. maltophila template DNA; Lane 4: DNA omitted

the PCR was performed on DNA extracted from the $P$. maltophila cells harvested from the TSA plates, and on DNA extracted from Carnobacterium piscicola and Corynebacterium aquaticum strains no bands were observed. However, the expected $500 \mathrm{bp}$ band was observed in the control samples of DNA extracted from $R$. salmoninarum cells (Figs. $1 \& 2$ )

Discussion. The first question addressed in this study was whether organisms possessing cross-reacting antigens, such as the $57 \mathrm{kDa}$ protein, would yield cross-

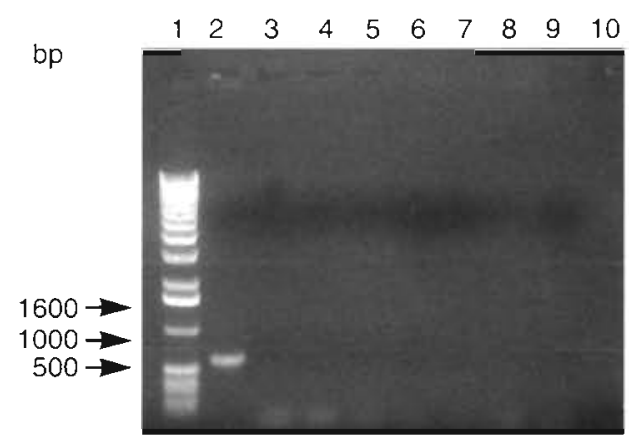

Fig. 2. Agarose gel electrophoresis of amplification products from DNA extracted from Renibacterium salmoninarum. Carnobacterium piscicola and Corynebacterium aquaticum isolates. Lane 1: molecular weight markers (base pairs, bp); Lane 2: $6.15 \mu \mathrm{g} \mathrm{ml}^{-1} R$. salmoninarum template DNA; Lane 3: DNA omitted; Lane 4: $7.44 \mu \mathrm{g} \mathrm{ml}^{-1}$ Carnobacterium pisicola ATCC 35586 template DNA; Lane 5: $7.44 \mathrm{\mu g} \mathrm{ml}^{-1}$ Carnobacterium piscicola PT-31 template DNA; Lane 6: $7.44 \mu \mathrm{g} \mathrm{ml}^{-1}$ Carnobacterium piscicola HB 425 template DNA; Lane 7 : $7.44 \mu \mathrm{g} \mathrm{ml}^{-1}$ Carnobacterium piscicola HB 426 template DNA; Lane 8: $7.50 \mu \mathrm{g} \mathrm{ml} \mathrm{m}^{-1}$ Corynebacterium aquaticum ATCC 14665 template DNA; Lane 9: $7.50 \mu \mathrm{g} \mathrm{ml}^{-1}$ Corynebacterium aquaticum 968 BA template DNA; Lane 10: empty 
reactions in the FAT and ELISA designed to detect Renibacterium salmoninarum. Our results show that none of the Carnobacterium piscicola and Corynebacterium aquaticum strains possessing this protein gave positive reactions in the FAT This result suggests that if the protein is a cell-surface protein, it must occur in amounts insufficient to obtain detectable cross reactions in the FAT. In the more sensitive ELISA, however, 1 of the 6 Carnobacterium piscicola/Corynebacterium aquaticum strains tested (Carnobacterium piscicola, strain PT-31) yielded a moderately strong cross reaction. In addition, our Pseudomonas maltophila isolate also yielded positive reactions in both the FAT and ELISA. These false-positive reactions provide further evidence for the limitations of the immunodiagnostic techniques currently in use for detecting $R$. salmoninarum infections. Also, they highlight the advantages of the specificity of the PCR for the detection of a gene that has been shown to encode a specific protcin that is apparently unique to $R$. salmoninarum. None of the bacteria other than $R$. salmoninarum were found to possess the p57 gene. Therefore, the $57 \mathrm{kDa}$ proteins expressed in Carnobacterium piscicola and Corynebacterium aquaticum are not p57; rather they are proteins of like size that share 1 or more epitopes with $\mathrm{p} 57$. Similarly, the uncharacterized but serologically reactive antigen present on the surface of $P$. maltophila cells, which caused a positive reaction in the FAT, is not $\mathrm{p} 57$ but rather an antigen also having epitopes in common with that protein.

Acknowledgements. The authors thank Mr J. E. Ketcheson and Mrs L. Prosperi-Porta at the Pacific Biological Station, and Ms S. Sanders at Hopkins Marine Station for their technical assistance. The donation of the Carnobacterium piscicola and Corynebacterium aquaticum strains by Dr A. Toranzo (Universidad de Santiago de Compostela, Spain) is gratefully acknowledged. We are grateful to the personnel of the Canadian Department of Fisheries and Oceans Robertson Creek Salmon Enhancement Hatchery for their field assistance. L.L.B. was supported by a Science Council of British Columbia Graduate Research and Engineering Training scholarship. This project was funded, in part, by operating grants to G.K.I. from the Natural Sciences and Engineering Research Council of Canada and the Canadian Bacterial Diseases Network, National Centres of Excellence, and by U.S. Fish and Wildlife grants (14-48-0009-92-1297 and 14-48-0009-92-1298) to R.P.L.

\section{LITERATURE CITED}

Austin B, Embley TM, Goodfellow M (1983) Selective isolation of Renibacterium salmoninarum. FEMS Microbiol Lett 17:111-114

Austin B, Rayment J (1985) Epizootiology of Renibacterium salmoninarum, the causal agent of bacterial kidney disease in salmonid fishes. J Fish Dis 8:505-509

Bandin I, Santos Y, Barja JL, Toranzo AE (1993) Detection of a common antigen among Renibacterium salmoninarum, Corynebacterium aquaticum, and Carnobacterium pisci-
Cola by the western blot technique. J aquat Anim Health 5 $172-176$

Barbash PA (1992) Spore-forming bacteria 1solated from fish feed found positive in direct fluorescent antibody test with Renibacterium salmoninarum antisera. Fish Health Section, Am Fish Soc Newsl 20(3):5-6

Brown LL, Iwama GK, Evelyn TPT, Nelson WS, Levine RP (1994) Use of the polymerase chain reaction (PCR) to detect DNA from Renibacterium salmoninarum within individual salmonid eggs. Dis aquat Org 18:165-171

Bullock GL, Griffin BR. Stuckey HM (1980) Detection of Corynebacterium salmoninus by direct fluorescent antibody test. Can J Fish Aquat Sci 37:719-721

Daly JG, Stevenson RMW (1985) Charcoal agar, a new growth medium for Renibacterium salmoninarum. Appl environ Microbiol 50:868-871

Dixon PF (1985) Rapid detection and identification of the fish pathogens by the enzyme-linked immunosorbent assay (ELISA). In: Ellis AE (ed) Fish and shellfish pathology. Academic Press, London, p 11-16

Elliott DG, Barila TY (1987) Membrane-filtration-fluorescent antibody staining procedure for detecting and quantifying Renibacterium salmoninarumin coelomic fluid of chinook salmon (Oncorhynchus tshawytscha). Can J Fish Aquat Sci 44:206-210

Elliott DG, Pascho RJ, Bullock GL (1989) Developments in the control of bacterial kidney disease of salmonid fishes. Dis aquat Org 6:201-215

Evelyn TPT, Ketcheson JE, Prosperi-Porta L (1981) The clinical significance of immunofluorescence-based diagnosis of the bacterial kidney disease carrier. Fish Pathol 15 $293-300$

Foott JS, Starliper CE, Walker RL, Junell D (1992) Pseudomonas isolate gives positive direct fluorescent antibody test using Renibacterium salmoninarum antisera. Fish Health Section, Am Fish Soc Newsl 20(1):2-3

Hsu HM, Bowser PR, Schachte JH Jr (1991) Development and evaluation of a monoclonal-antibody-based enzymelinked immunosorbent assay for the diagnosis of Renibacterium salmoninarum infection. I aquat Anim Health 3: $168-175$

Meyers TR, Short S, Farrington C, Lipson K, Geiger HJ, Gates $R$ (1993) Establishment of a negative-positive threshold optical density value for the enzyme-linked immunosorbent assay (ELISA) to detect soluble antigen of Renibacterium salmoninarum in Alaskan Pacific salmon. Dis aquat Org 16:191-197

Olivier G, Griffiths SG, Fildes S, Lynch WH (1992) The use of the western blot and electroimmunotransfer blot assays to monitor bacterial kidney disease in experimentally challenged Atlantic salmon, Salmo salar. J Fish Dis 15: 229-241

Rockey DD, Gilkey LL, Wiens GD, Kaattari SL (1991) Monoclonal antibody-based analysis of the Renibacterium salmoninarum 57 protein in spawning chinook and coho salmon. $J$ aquat Anim Health 3:23-30

Sakai M, Atsuta S, Kobayashi M (1992) Detection of Renibacterium salmoninarum antigen in migrating adult salmon (Oncorhynchus keta) in Japan. J Wildl Dis 28:110-112

Sambrook J. Fritsch EF, Maniatis I (1989) Molecular cloning - a laboratory manual. Cold Spring Harbor Laboratory Press, Cold Spring Harbor, NY

Toranzo AE, Romalde JL, Nuñez S, Figueras A, Barja JL (1993) An epizootic in farmed, market-size rainbow trout in Spain caused by a strain of Carnobacterium piscicola of unusual virulence. Dis aquat Org 17:87-89

Turaga PSD, Wiens GD, Kaattari SL (1987) Analysis of Renı- 
bacterium salmoninarum antigen production in situ. Fish Pathol 22:209-214

Wiens GD, Kaattari SL (1989) Monoclonal antibody analysis of common surface protein(s) of Renibacterium salmoninarum. Fish Pathol 24:1-7

Editorial responsibility: Managing Editor
Yoshımizu M, Ji R, Nomura T, Kimura T (1987) A false positive reaction in the indirect fluorescent antibody test for Renibacterium salmoninarum ATCC 33209 caused by a Pseudomonas sp. Sci Rep Hokkaido Salmon Hatchery 41. $121-127$

Manuscript first received: October 21, 1994 Revised version accepted: January 26, 1995 